\title{
Practice Patterns for the Acceptance of Medically Complex Living Kidney Donors with Hematuria, Sickle Cell Trait, Smoking, Illegal Drug Use, or Urological Issues: A Multinational Survey
}

\author{
Ziad Arabi ${ }^{1}$ Abdullah Hamad ${ }^{2}$ Muhammad Bukhari ${ }^{3}$ \\ ${ }^{1}$ Department of the Organ Transplant Center, Division of Adult \\ Transplant Nephrology, King Abdulaziz Medical City, King Abdullah \\ International Medical Research Center, King Saud Bin Abdulaziz \\ University for Health Sciences, Riyadh, Saudi Arabia \\ 2 Department of Medicine, Division of Nephrology, Regional Medical \\ Center of Orangeburg and Calhoun Counties, Orangeburg, South \\ Carolina, United Sates \\ ${ }^{3}$ Department of Medicine, Division of Adult Nephrology, Taif \\ University, Taif, Saudi Arabia \\ ${ }^{4}$ Department of Medicine, Division of Nephrology, CHU Clermont- \\ Ferrand, France
}

Abdulrahman Altheaby ${ }^{1}{ }^{\circledR}$ Saleh Kaysi ${ }^{4}$

\author{
Address for correspondence Ziad Arabi, MD, Department of the \\ Organ Transplant Center, Division of Adult Transplant Nephrology, \\ King Abdulaziz Medical City, Riyadh, Saudi Arabia \\ (e-mail: ziadarabi@yahoo.com).
}

Avicenna J Med 2021;11:185-195.

Abstract
Keywords
- drug use
- Extended criteria
- Hematuria
- kidney stone
- Living kidney donor
- Multi-national survey
- renal cyst
- sickle cell trait
- smoking
- Survey

Background To review the practice patterns for the acceptance of medically complex living kidney donors (MCLKD) among the transplant providers of the international transplant community.

Methods We distributed a survey globally, through major international transplantation societies, among nephrologists and transplant surgeons (TS). The survey contained questions regarding potential donors with microscopic hematuria, sickle cell trait, renal cysts, kidney stones, smoking, or illegal drug use.

Results There were 239 respondents from 29 countries, including nephrologists (42\%) and TS (58\%). Although most respondents would investigate microscopic hematuria, one-third of them indicated they would decline these potential donors without investigation. Interestingly, most respondents accepted heavy smokers, intermittent illegal drug users (with advice to quit), and those with incidentally identified kidney stones, remote history of renal colic or simple renal cysts. We found multiple areas of consensus in practice with some interesting differences between nephrologists and TS.

Conclusions This survey highlights the practice patterns of the acceptance of MCLKDs among the international community. In the absence of clear guidelines, this survey provides additional information to counsel kidney donors with microscopic hematuria, sickle cell trait, renal cysts, kidney stones, heavy smoking, or illegal drug use. published online

November 15, 2021
DOI https://doi.org/ $10.1055 / \mathrm{s}-0041-1736542$. ISSN 2231-0770.
(C) 2021. Syrian American Medical Society. All rights reserved. This is an open access article published by Thieme under the terms of the Creative Commons Attribution-NonDerivative-NonCommercial-License, permitting copying and reproduction so long as the original work is given appropriate credit. Contents may not be used for commercial purposes, or adapted, remixed, transformed or built upon. (https://creativecommons.org/ licenses/by-nc-nd/4.0/)

Thieme Medical and Scientific Publishers Pvt. Ltd., A-12, 2nd Floor, Sector 2, Noida-201301 UP, India 


\section{Introduction}

Potential living kidney donors (KDs) are frequently found to have borderline medical or surgical abnormalities that complicate decision-making in kidney donation. These potential donors are often referred to as medically complex living kidney donors (MCLKDs). Examples include potential donors with isolated microscopic hematuria (IMH), sickle cell trait (SCT), simple renal cysts, kidney stones, heavy smoking, or intermittent illegal drug use (IIDU) habit. ${ }^{1}$ The exact prevalence of MCLKDs in the entire donor pool is unknown; however, they may constitute at least $25 \%$ of the total living donor pool. ${ }^{2}$

Kidney donation carries potential, although small, longterm risks, especially end-stage kidney disease (ESKD), for donors. $^{3-6}$ These risks are potentially higher in MCLKDs. Guidelines of kidney donation do not address some of the controversial issues related to MCLKDs. ${ }^{7-9}$ Similarly, online calculators are not designed to estimate the future risk of ESKD after kidney donation of MCLKDs. ${ }^{10,11}$ For these reasons, centers and experts may differ in their perspectives on the suitability and acceptance of MCLKDs. ${ }^{12,13}$

This study aimed to assess the variability of practice patterns in the acceptance of MCLKDs.

\section{Materials and Methods}

The survey was formulated based on a thorough literature review, ${ }^{1,2,12-14}$ group discussions, and controversies highlighted in conferences.

Our survey consisted of 30 questions. The first 5 questions gathered demographic data of the participants. The next 17 questions are discussed in our concurrent submission. Here, we discuss the 8 remaining core questions, which are grouped into the following four domains: (1) isolated microscopic hematuria (1 question), (2) SCT (1 question), (3) active heavy smoking or IIDU (2 questions), and (4) potential donors with urological issues including kidney stones (2 questions), simple renal cysts (1 question), and/or abnormal nuclear renal scan findings (1 question).

After obtaining institutional review board (IRB) approval (RC19/149/R), the cross-sectional survey was deployed using SurveyMonkey. Six international transplant societies were approached to distribute the survey to their member nephrologists and transplant surgeons (TS). However, only the American Society of Transplantation (AST), the American Society of Transplant Surgeons (ASTS), and the European Renal Association-European Dialysis and Transplant Association (ERA-EDTA) responded. The other three transplant societies did not participate.

The survey was distributed between June 2019 and February 2020 by the societies according to their policies (AST: through the society email and directly to the members of living donor and kidney and pancreas communities with 5 subsequent reminders; ERA-EDTA: by publishing the survey on its website; and ASTS: through the "survey rental" of the society by emailing the members with 5 subsequent reminders). Appropriate web consent was obtained, and the participants were requested to choose the most suitable option from the given scenarios. There was no identity attached to the questioner or to the responses.

The inclusion criteria were as follows: practicing nephrologists and TS. In training or nonpracticing nephrologists or TS were excluded.

\section{Statistical Analyses}

The frequency of the responses was reported as the number and percentage of nephrologists, TS, and total number of participants. SPSS (IBM Corp. Released 2016. IBM SPSS Statistics for Windows, Version 24.0. Armonk, NY) was used for data analysis. Comparisons were performed using the $\chi^{2}$ test or Fisher's exact test, as appropriate. Linear regression was used to examine the association between specialty, experience duration, donor and recipient assessment frequency as independent variables and the number of questions answered "allow for transplant" or "decline for transplant" as dependent variables. Spearman correlation was used to test the association between the selected countries and the rate of acceptance of patients with SCT. Two-sided $p$-values of less than 0.05 were considered statistically significant.

\section{Results}

\section{Participant Demographics}

A total of 239 nephrologists and TS from 29 countries responded to the survey. Nephrologists comprised $42 \%$ $(n=100)$ of the respondents, while $58 \%(n=139)$ were TS. The majority of the respondents were from the United States $(64 \%, n=154)$. Most of the respondents (77\%) had significant experience ( $>6$ years in practice) and were closely involved in donor evaluation (-Table 1 ).

Among the respondents of this survey, TS were more involved in donors' evaluations, and their country of practice was more likely in the United States (-Table 1). However, after adjustment for the number of years in practice or degree of involvement in pretransplant evaluation of donors and recipients, multivariate regression analysis did not show any significant attributable differences in the survey responses. The overall views of nephrologists and TS on the suitability and acceptance of MCLKDs were the core subject of this study, and they have been presented in detail below (-Tables 1-6).

The response rates were as follows: $5.5 \%$ of the AST community, $10.4 \%$ of ASTS and unknown percentage of ERA-EDTA (46 responses were received after the web posting by ERA-EDTA, as mentioned above). The completion rate was $99 \%$ (i.e., $99 \%$ of those who started the survey completed it).

\section{Medically Complex Medical Conditions in Living Kidney Donors}

Isolated Microscopic Hematuria

Interestingly, only $12.2 \%$ of the respondents permitted donation without further investigation in potential donors with 
Table 1 Participant demographics

\begin{tabular}{|c|c|c|c|c|c|}
\hline \multirow[t]{3}{*}{ Characteristic } & \multirow[t]{3}{*}{ Answers } & \multicolumn{2}{|l|}{$n(241)$} & \multirow[t]{3}{*}{$p$-Value } & \multirow[b]{2}{*}{ Total } \\
\hline & & Nephrologists & Transplant surgeons & & \\
\hline & & $\begin{array}{l}100 \\
(41.5 \%)\end{array}$ & $\begin{array}{l}139 \\
(57.7 \%)\end{array}$ & & $\begin{array}{l}239 \\
(100 \%)\end{array}$ \\
\hline \multirow[t]{4}{*}{ Practice } & $<1$ year & $\begin{array}{l}3 \\
3 \%\end{array}$ & $\begin{array}{l}2 \\
1.4 \%\end{array}$ & 0.022 & $\begin{array}{l}5 \\
2.1 \%\end{array}$ \\
\hline & $1-5$ years & $\begin{array}{l}29 \\
29 \%\end{array}$ & $\begin{array}{l}19 \\
13.7 \%\end{array}$ & & $\begin{array}{l}48 \\
20.1 \%\end{array}$ \\
\hline & $6-10$ years & $\begin{array}{l}14 \\
14 \%\end{array}$ & $\begin{array}{l}24 \\
17.3 \%\end{array}$ & & $\begin{array}{l}38 \\
15.9 \%\end{array}$ \\
\hline & more than 10 years. & $\begin{array}{l}54 \\
54 \%\end{array}$ & $\begin{array}{l}94 \\
67.6 \%\end{array}$ & & $\begin{array}{l}148 \\
61.9 \%\end{array}$ \\
\hline \multirow{4}{*}{$\begin{array}{l}\text { Do you assess } \\
\text { donors for } \\
\text { pretransplant } \\
\text { workup? }\end{array}$} & On a weekly basis. & $\begin{array}{l}50 \\
50 \%\end{array}$ & $\begin{array}{l}77 \\
55.4 \%\end{array}$ & 0.006 & $\begin{array}{l}127 \\
53.1 \%\end{array}$ \\
\hline & On a monthly basis. & $\begin{array}{l}15 \\
15 \%\end{array}$ & $\begin{array}{l}36 \\
25.9 \%\end{array}$ & & $\begin{array}{l}51 \\
21.3 \%\end{array}$ \\
\hline & Not on a regular basis. & $\begin{array}{l}21 \\
21 \%\end{array}$ & $\begin{array}{l}21 \\
15.1 \%\end{array}$ & & $\begin{array}{l}42 \\
17.6 \%\end{array}$ \\
\hline & I do not do donor assessment. & $\begin{array}{l}14 \\
14 \%\end{array}$ & $\begin{array}{l}5 \\
3.6 \%\end{array}$ & & $\begin{array}{l}19 \\
7.9 \%\end{array}$ \\
\hline \multirow{5}{*}{$\begin{array}{l}\text { Do you assess } \\
\text { recipients for } \\
\text { pretransplant } \\
\text { workup? }\end{array}$} & On a weekly basis. & $\begin{array}{l}55 \\
55 \%\end{array}$ & $\begin{array}{l}113 \\
81.9 \%\end{array}$ & $<0.001$ & $\begin{array}{l}168 \\
70.6 \%\end{array}$ \\
\hline & On a monthly basis. & $\begin{array}{l}16 \\
16 \%\end{array}$ & $\begin{array}{l}15 \\
10.9 \%\end{array}$ & & $\begin{array}{l}31 \\
13 \%\end{array}$ \\
\hline & Not on a regular basis. & $\begin{array}{l}11 \\
11 \%\end{array}$ & $\begin{array}{l}8 \\
5.8 \%\end{array}$ & & $\begin{array}{l}19 \\
8 \%\end{array}$ \\
\hline & $\begin{array}{l}\text { I do not do a pre-transplant assessment, but I } \\
\text { see postrenal transplant patients. }\end{array}$ & $\begin{array}{l}6 \\
6 \%\end{array}$ & $\begin{array}{l}1 \\
0.7 \%\end{array}$ & & $\begin{array}{l}7 \\
2.9 \%\end{array}$ \\
\hline & $\begin{array}{l}\text { I do not do a pretransplant assessment and I } \\
\text { do not follow renal transplant patients. }\end{array}$ & $\begin{array}{l}12 \\
12 \%\end{array}$ & $\begin{array}{l}1 \\
0.7 \%\end{array}$ & & $\begin{array}{l}13 \\
5.5 \%\end{array}$ \\
\hline \multirow[t]{6}{*}{ Country } & United States & $\begin{array}{l}42 \\
42.4 \%\end{array}$ & $\begin{array}{l}112 \\
81.8 \%\end{array}$ & $<0.001$ & $\begin{array}{l}154 \\
65.3 \%\end{array}$ \\
\hline & Saudi Arabia & $\begin{array}{l}9 \\
9.1 \%\end{array}$ & $\begin{array}{l}4 \\
2.9 \%\end{array}$ & & $\begin{array}{l}13 \\
5.5 \%\end{array}$ \\
\hline & Pakistan & $\begin{array}{l}10 \\
10.1 \%\end{array}$ & $\begin{array}{l}2 \\
1.5 \%\end{array}$ & & $\begin{array}{l}12 \\
5.1 \%\end{array}$ \\
\hline & Sudan & $\begin{array}{l}8 \\
8.1 \% \\
\end{array}$ & $\begin{array}{l}1 \\
0.7 \% \\
\end{array}$ & & $\begin{array}{l}9 \\
3.8 \%\end{array}$ \\
\hline & Canada & $\begin{array}{l}4 \\
4 \%\end{array}$ & $\begin{array}{l}4 \\
2.9 \%\end{array}$ & & $\begin{array}{l}8 \\
3.4 \%\end{array}$ \\
\hline & Other & $\begin{array}{l}26 \\
26.3 \%\end{array}$ & $\begin{array}{l}14 \\
10.2 \%\end{array}$ & & $\begin{array}{l}40 \\
15.9 \%\end{array}$ \\
\hline
\end{tabular}

mild IMH (presence of 4 red blood cells on repeated urine analysis and trace hematuria using the dipstick method). The majority of the respondents (57\%) suggested kidney biopsy prior to proceeding to the next step. Many respondents (30.7\%) chose to consider alternative donors to avoid the hassle of kidney biopsy, which may be inconclusive and not affect the end result.

There was no difference between the responses of TS and nephrologists in requesting kidney biopsy (64.0\% vs. $52.2 \%$, respectively) or in rejecting such potential donors (29.0\% vs.
$31.9 \%$, respectively; $p=0.06$ ). - Table 2 presents the suitability and acceptance of MCLKDs with IMH.

\section{Sickle Cell Trait}

The presence of SCT was considered a contraindication for donor nephrectomy by nearly half of the respondents (48\%). However, $52 \%$ of the respondents accepted such donors in the following cases: (a) after counselling about the risks involved (28\%) or (b) if no alternative donor was available (24\%). There was no statistically significant difference 
Table 2 The acceptance of the MCLKDs with microscopic hematuria

\begin{tabular}{|c|c|c|c|c|c|}
\hline Question & Answer choices & Nephro & TS & $p$-Value & Total \\
\hline \multirow{3}{*}{$\begin{array}{l}\text { Q1. The donor is a } 35 \text {-year- } \\
\text { old nonsmoking man } \\
\text { with IMH (4 RBC on } \\
\text { repeated UA and trace } \\
\text { hematuria on } \\
\text { dipstick) and negative } \\
\text { imaging. }\end{array}$} & $\begin{array}{l}\text { I will allow this donor to donate without } \\
\text { further testing. }\end{array}$ & $\begin{array}{l}7 \\
7 \%\end{array}$ & $\begin{array}{ll}22 \\
15.9 \%\end{array}$ & \multirow[t]{3}{*}{0.068} & $\begin{array}{l}29 \\
12.2 \%\end{array}$ \\
\hline & I will ask for a renal biopsy. & $\begin{array}{l}64 \\
64 \%\end{array}$ & $\begin{array}{l}72 \\
52.2 \%\end{array}$ & & $\begin{array}{l}136 \\
57.1 \%\end{array}$ \\
\hline & $\begin{array}{l}\text { I will ask for an alternative donor to avoid } \\
\text { the hassle of kidney biopsy which may not } \\
\text { change the management. }\end{array}$ & $\begin{array}{l}29 \\
29 \%\end{array}$ & $\begin{array}{l}44 \\
31.9 \%\end{array}$ & & $\begin{array}{l}73 \\
30.7 \%\end{array}$ \\
\hline
\end{tabular}

Abbreviations: IMH, isolated microscopic hematuria; Nephro, nephrologists; TS, transplant surgeon; UA, urine analysis.

Table 3A The acceptance of the MCLKD with SCT

\begin{tabular}{|c|c|c|c|c|c|}
\hline Question & Answer Choices & Nephro & TS & $p$-Value & Total \\
\hline \multirow[t]{3}{*}{ Q2. A donor with SCT } & I will clear him for donation after counselling. & $\begin{array}{l}25 \\
25 \%\end{array}$ & $\begin{array}{l}41 \\
29.9 \%\end{array}$ & \multirow[t]{3}{*}{0.183} & $\begin{array}{l}66 \\
27.8 \%\end{array}$ \\
\hline & $\begin{array}{l}\text { I will advise him against donation. However, I } \\
\text { will allow the donation if no alternative donor } \\
\text { is available. }\end{array}$ & $\begin{array}{l}30 \\
30 \%\end{array}$ & $\begin{array}{l}27 \\
19.7 \%\end{array}$ & & $\begin{array}{l}57 \\
24.1 \%\end{array}$ \\
\hline & I will not clear him. & $\begin{array}{l}45 \\
45 \%\end{array}$ & $\begin{array}{l}69 \\
50.4 \%\end{array}$ & & $\begin{array}{l}114 \\
48.1 \%\end{array}$ \\
\hline
\end{tabular}

Abbreviations: MCLKD, medically complex living kidney donor; Nephro, nephrologists; SCT, sickle cell trait; TS, transplant surgeon.

Table 3B The rate of decline of SCT donors and the prevalence of SCT in their countries

\begin{tabular}{|l|l|l|l|}
\hline Country & Rate of decline of SCT & Prevalence of SCT & $p^{*}$-Value \\
\hline United States & $53.30 \%$ & $1.5 \%$ & $p=0.005$ \\
\hline Canada & $62.50 \%$ & Unknown \\
\hline Kingdom of Saudi Arabia & $23.10 \%$ & $2-27 \%$ & $11-30 \%$ \\
\hline Sudan & $33.30 \%$ & $4 \%$ & \\
\hline Pakistan & $25.00 \%$ & & \\
\hline
\end{tabular}

Abbreviation: SCT, sickle cell trait.

A significant negative correlation (a Spearman Rho of $r=-0.202$ and $p=0.005$ values).

*References ${ }^{14-17}$

between the responses of nephrologists and TS regarding donors with SCT. The rejection rate of donors with SCT varied among countries (Canada: 62.50\%; the United States: 53.30\%; Sudan: 33.30\%; Pakistan: 25.00\%: and Kingdom of Saudi Arabia: $23.10 \%$ ) and negatively correlated with the prevalence of SCT in these countries $(p=0.005)^{14-19}$ ( - Tables 3A and $3 \mathrm{~B})$.

Active Heavy Smoking or Intermittent Illegal Drug Use Notably, most of the respondents permitted donation from active heavy smokers, with advice to quit, especially in cases of nonavailability of other donors (accept: 61.9\%; reject: $38 \%)$. TS rejected active smokers more than nephrologists (46\% vs. $26 \%$, respectively; $p<0.0001$ ).

Of the respondents, 55\% ultimately accepted potential donors who intermittently used illegal drugs (after counselling) in cases of nonavailability of alternative donors, whereas $45 \%$ rejected such donors. There was no statistically significant difference between TS and nephrologists regarding the acceptance or rejection of potential donors who intermittently used illegal drugs.

On comparison of IIDU with heavy smoking, a smaller number of respondents more readily accepted potential donors who used illegal drugs (after psychiatric counselling) than donors who were active heavy smokers ( $29.7 \%$ vs. $43.9 \%$, respectively; $p=0.006$ ).

-Table 4 presents the suitability and acceptance of MCLKDs with active heavy smoking habit or intermittent drug abuse.

\section{Urological Issues}

Donors with simple renal cysts: The majority of respondents accepted such potential donors (94\%) after counselling. Furthermore, 90\% of the respondents selected the cystbearing kidney. Nephrologists and TS reported a similar approach toward such potential donors $(p=0.111)$. 
Practice Patterns for the Acceptance of Medically Complex Living Kidney Donors Arabi et al. 189

Table 4 The acceptance of the MCLKD with heavy smoking or IIDU

\begin{tabular}{|c|c|c|c|c|c|}
\hline Question & Answer choices & Nephro & TS & $p$-Value & Total \\
\hline \multirow[t]{3}{*}{$\begin{array}{l}\text { Q3. The donor is an active } \\
\text { smoker (2 PPD) }\end{array}$} & $\begin{array}{l}\text { I will allow him to donate } \\
\text { however he needs to quit } \\
\text { smoking later. }\end{array}$ & $\begin{array}{l}62 \\
62 \%\end{array}$ & $\begin{array}{l}43 \\
30.9 \%\end{array}$ & \multirow[t]{3}{*}{$<0.0001$} & $\begin{array}{l}105 \\
43.9 \%\end{array}$ \\
\hline & $\begin{array}{l}\text { I will advise him not to } \\
\text { donate but I will allow the } \\
\text { donation if no alternative } \\
\text { donor is available. }\end{array}$ & $\begin{array}{l}12 \\
12 \%\end{array}$ & $\begin{array}{l}31 \\
22.3 \%\end{array}$ & & $\begin{array}{l}43 \\
18 \%\end{array}$ \\
\hline & I will DECLINE this donor. & $\begin{array}{l}26 \\
26 \%\end{array}$ & $\begin{array}{l}65 \\
46.8 \%\end{array}$ & & $\begin{array}{l}91 \\
38.1 \%\end{array}$ \\
\hline \multirow{3}{*}{$\begin{array}{l}\text { Q4. If the donor admits } \\
\text { the use of illegal } \\
\text { drugs intermittently } \\
\text { (last use } 2 \text { months } \\
\text { ago) }\end{array}$} & $\begin{array}{l}\text { I will allow him to donate } \\
\text { after psychiatric } \\
\text { counselling. }\end{array}$ & $\begin{array}{l}29 \\
29 \%\end{array}$ & $\begin{array}{l}42 \\
30.2 \%\end{array}$ & \multirow[t]{3}{*}{0.949} & $\begin{array}{l}71 \\
29.7 \%\end{array}$ \\
\hline & $\begin{array}{l}\text { I will advise him not to } \\
\text { donate but I will allow the } \\
\text { donation if no alternative } \\
\text { donor and only after } \\
\text { psychiatric counselling. }\end{array}$ & $\begin{array}{l}25 \\
25 \%\end{array}$ & $\begin{array}{l}36 \\
25.9 \%\end{array}$ & & $\begin{array}{l}61 \\
25.5 \%\end{array}$ \\
\hline & I will DECLINE this donor. & $\begin{array}{l}46 \\
46 \%\end{array}$ & $\begin{array}{l}61 \\
43.9 \%\end{array}$ & & $\begin{array}{l}107 \\
44.8 \%\end{array}$ \\
\hline
\end{tabular}

Abbreviations: IIDU, intermittent illegal drug use; MCLKD, medically complex living kidney donor; Nephro, nephrologists; PPD, packs per day; TS, transplant surgeon.

Table 5 The acceptance of the MCLKD regarding urological issues

\begin{tabular}{|c|c|c|c|c|c|}
\hline Question & Answer choices & Nephro & TS & p-Value & Total \\
\hline \multirow{4}{*}{$\begin{array}{l}\text { Q5. A 40-year-old donor } \\
\text { with a stable } 5 \text {-cm } \\
\text { simple cyst of the left } \\
\text { kidney: }\end{array}$} & $\begin{array}{l}\text { I will allow him to donate } \\
\text { his left kidney after } \\
\text { counselling. }\end{array}$ & $\begin{array}{l}85 \\
85 \%\end{array}$ & $\begin{array}{l}131 \\
94.2 \%\end{array}$ & \multirow[t]{4}{*}{0.111} & $\begin{array}{l}216 \\
90.4 \%\end{array}$ \\
\hline & $\begin{array}{l}\text { I will allow him to donate } \\
\text { his right kidney after } \\
\text { counselling. }\end{array}$ & $\begin{array}{l}5 \\
5 \%\end{array}$ & $\begin{array}{l}3 \\
2.2 \%\end{array}$ & & $\begin{array}{l}8 \\
3.3 \%\end{array}$ \\
\hline & $\begin{array}{l}\text { I will advise him against } \\
\text { donation. However, I will } \\
\text { clear him if no alternative } \\
\text { donor. }\end{array}$ & $\begin{array}{l}6 \\
6 \%\end{array}$ & $\begin{array}{l}3 \\
2.2 \%\end{array}$ & & $\begin{array}{l}9 \\
3.8 \%\end{array}$ \\
\hline & I will DECLINE this donor. & $\begin{array}{l}4 \\
4 \%\end{array}$ & $\begin{array}{l}2 \\
1.4 \%\end{array}$ & & $\begin{array}{l}6 \\
2.5 \%\end{array}$ \\
\hline \multirow{4}{*}{$\begin{array}{l}\text { Q6. Donor with 2-mm } \\
\text { stone in the lower } \\
\text { pole of the left kidney } \\
\text { seen on CT scan } \\
\text { otherwise } \\
\text { asymptomatic: }\end{array}$} & $\begin{array}{l}\text { I will allow him to donate } \\
\text { his left kidney after } \\
\text { counselling. }\end{array}$ & $\begin{array}{l}72 \\
72 \%\end{array}$ & $\begin{array}{l}122 \\
88.4 \%\end{array}$ & \multirow[t]{4}{*}{0.002} & $\begin{array}{l}194 \\
81.5 \%\end{array}$ \\
\hline & $\begin{array}{l}\text { I will allow him to donate } \\
\text { his right kidney after } \\
\text { counselling. }\end{array}$ & $\begin{array}{l}5 \\
5 \%\end{array}$ & $\begin{array}{l}0 \\
0 \%\end{array}$ & & $\begin{array}{l}5 \\
2.1 \%\end{array}$ \\
\hline & $\begin{array}{l}\text { I will advise him against } \\
\text { donation. However, I will } \\
\text { clear him if no alternative } \\
\text { donor. }\end{array}$ & $\begin{array}{l}14 \\
14.0 \%\end{array}$ & $\begin{array}{l}7 \\
5.1 \%\end{array}$ & & $\begin{array}{l}21 \\
8.8 \%\end{array}$ \\
\hline & I will DECLINE this donor. & $\begin{array}{l}9 \\
9 \%\end{array}$ & $\begin{array}{l}9 \\
6.5 \%\end{array}$ & & $\begin{array}{l}18 \\
7.6 \%\end{array}$ \\
\hline \multirow{2}{*}{$\begin{array}{l}\text { Q7. A 30-year-old man with } \\
\text { a history of a single } \\
\text { episode of left renal } \\
\text { colic } 5 \text { years ago. His } \\
\text { current CT scan and } \\
\text { urine collection are } \\
\text { negative: }\end{array}$} & $\begin{array}{l}\text { I will allow him to donate } \\
\text { his left kidney after } \\
\text { counselling. }\end{array}$ & $\begin{array}{l}85 \\
85 \%\end{array}$ & $\begin{array}{l}120 \\
87.6 \%\end{array}$ & \multirow[t]{2}{*}{0.820} & $\begin{array}{l}205 \\
86.5 \%\end{array}$ \\
\hline & $\begin{array}{l}\text { I will allow him to donate } \\
\text { his right kidney after } \\
\text { counselling. }\end{array}$ & $\begin{array}{l}2 \\
2 \%\end{array}$ & $\begin{array}{l}1 \\
0.7 \%\end{array}$ & & $\begin{array}{l}3 \\
1.3 \%\end{array}$ \\
\hline
\end{tabular}


Table 5 (Continued)

\begin{tabular}{|c|c|c|c|c|c|}
\hline Question & Answer choices & Nephro & TS & $p$-Value & Total \\
\hline & $\begin{array}{l}\text { I will advise him against } \\
\text { donation. However, I will } \\
\text { clear him if no alternative } \\
\text { donor. }\end{array}$ & $\begin{array}{l}9 \\
9 \%\end{array}$ & $\begin{array}{l}10 \\
7.3 \%\end{array}$ & & $\begin{array}{l}19 \\
8.0 \%\end{array}$ \\
\hline & I will DECLINE this donor. & $\begin{array}{l}4 \\
4 \%\end{array}$ & $\begin{array}{l}6 \\
4.4 \%\end{array}$ & & $\begin{array}{l}10 \\
4.2 \%\end{array}$ \\
\hline \multirow{4}{*}{$\begin{array}{l}\text { Q8. A donor with normal } \\
\text { ultrasound but } \\
\text { nuclear renogram } \\
\text { showed a } \\
\text { discrepancy of renal } \\
\text { functions (split GFR of } \\
30 \% \text { in the right and } \\
70 \% \text { in the left): }\end{array}$} & $\begin{array}{l}\text { I will allow him to donate } \\
\text { his left kidney after } \\
\text { counselling. }\end{array}$ & $\begin{array}{l}2 \\
2 \%\end{array}$ & $\begin{array}{l}3 \\
2.2 \%\end{array}$ & \multirow[t]{4}{*}{0.001} & $\begin{array}{l}5 \\
2.1 \%\end{array}$ \\
\hline & $\begin{array}{l}\text { will allow him to donate } \\
\text { his right kidney after } \\
\text { counselling. }\end{array}$ & $\begin{array}{l}20 \\
20 \%\end{array}$ & $\begin{array}{l}62 \\
45.3 \%\end{array}$ & & $\begin{array}{l}82 \\
34.6 \%\end{array}$ \\
\hline & $\begin{array}{l}\text { I will advise him against } \\
\text { donation. However, I will } \\
\text { allow the donation if no } \\
\text { alternative donor is } \\
\text { available. }\end{array}$ & $\begin{array}{l}9 \\
9 \%\end{array}$ & $\begin{array}{l}8 \\
5.8 \%\end{array}$ & & $\begin{array}{l}17 \\
7.2 \%\end{array}$ \\
\hline & I will DECLINE this donor. & $\begin{array}{l}69 \\
69 \%\end{array}$ & $\begin{array}{l}64 \\
46.7 \%\end{array}$ & & $\begin{array}{l}133 \\
56.1 \%\end{array}$ \\
\hline
\end{tabular}

Abbreviations: CT, computed tomography; GFR, glomerular filtration rate; Nephro, nephrologists; TS, transplant surgeon.

Incidentally identified small $(2-3 \mathrm{~mm})$ renal stones: $81 \%$ of the respondents permitted donation of the stone-bearing kidney. Only $7 \%$ of the respondents rejected such donors. TS were more likely to accept such potential donors than nephrologists ( $88 \%$ vs. $77 \%$, respectively; $p=0.002$ ).

Remote history of a single episode of renal colic: $86 \%$ of the respondents permitted donation of the stone-bearing kidney after counselling, whereas $8 \%$ permitted donation only in the absence of substitutes.

Most of the participants (56\%) chose to reject potential donors with significant discrimination of kidney function, as determined by a nuclear isotope scan, whereas $35 \%$ permitted donation with nephrectomy of the less functioning kidney. TS were equally divided between choosing the less functioning kidney versus rejecting the donation (45\% vs. $46 \%$, respectively). However, TS were less likely to reject such candidates than nephrologists ( $47 \%$ vs. $69 \%$, respectively; $p=0.001$ ).

-Table 5 presents the suitability and acceptance of MCLKDs with urological issues.

\section{Discussion}

\section{Isolated Microscopic Hematuria}

IMH is defined as 3 or more red blood cells per high-power field on microscopic evaluation of urinary sediments from at least two properly collected urine specimens. ${ }^{20} \mathrm{~A}$ study conducted in 2017 reported that transplantation programs equally diagnosed IMH based on the presence of 3 or 5 red blood cells. ${ }^{20}$ The urine dipstick method alone is inadequate for establishing a diagnosis of isolated microscopic hematuria, and microscopic evaluation of the urinary sediment should be performed to confirm the results. IMH was reported to be present in up to $8 \%$ of the total number of potential KDs. ${ }^{21}$

IMH can be caused by extraglomerular bleeding due to the presence of stones, hemoglobinopathy (SS/SA hemoglobin), cystic kidney disease, benign prostatic hyperplasia, or malignancy (bladder, kidney, or prostate). Exclusion of these conditions warrants proper urological evaluation by computed tomography (CT) and/or cystoscopy. Glomerular causes of IMH include thin basement membrane nephropathy (TBMN), IgA nephropathy (IgAN), or early stage Alport syndrome (AS) or Alport carrier. A kidney biopsy is indicated to clarify the glomerular origin of IMH.

Kidney biopsy findings in MCLKDs with IMH vary based on the age of the donor, the population, and family history of kidney disease. ${ }^{22-24}$ A study involving 54 donors with IMH reported normal biopsy findings in up to $60 \%$ of the cases. ${ }^{22}$ Potential pathological findings reported in studies include TBMN (50\%), nonspecific findings (mild mesangiopathy or nonspecific interstitial changes) (30\%), IgAN (14\%), unexpected form of glomerular disease (5\%), AS, or Alport carrier status. $22-24$

Differentiation of TBMN from early AS or Alport carrier status is crucial but can be challenging, even with the use of electron microscopy and immunostaining. ${ }^{25}$ Genetic testing has been reported to be helpful in such cases. ${ }^{26}$

Donors with AS or IgAN are not potential candidates for donation. Potential donors with TBMN are typically accepted for donation. ${ }^{27}$ However, TBMN has been reported to be associated with an increased risk in chronic kidney disease (CKD), in cases of positive family history of CKD, ${ }^{28}$ evidence of extrarenal manifestations, or presence of glomerular basement membrane lamellation. ${ }^{25,29}$ A study conducted in 2007 reported that $43 \%$ of the transplantation programs 
in the United States routinely excluded donor candidates with thin basement membrane disease. ${ }^{20}$

Kidney biopsy is an invasive procedure, and postbiopsy findings frequently preclude kidney donation. Donors with medical conditions should be counselled about these facts prior to committing to kidney biopsy. A survey of transplantation programs in the United States conducted in 2017 revealed that only $1 \%$ of the programs rejected a kidney donor with hematuria without further investigations, ${ }^{20}$ whereas $30 \%$ of the respondents from the United States in our survey reported rejecting such donors. We feel, based on the futility of work up in many cases, that the $30 \%$ rejection rate of donors with microscopic hematuria may represent the actual percentage of the clinical scenario.

In our survey, young potential KDs with persistent IMH (including mild degree) were required to undergo further evaluation involving kidney biopsy before donation. However, up to one-third of the nephrologists and TSs considered alternative donors to avoid the hassle of kidney biopsy, which can be borderline or inconclusive.

\section{Sickle Cell Disease}

Sickle cell disease (SCD) affects millions of people worldwide. ${ }^{18,30}$ SCT is associated with fewer renal complications than SCD; nonetheless, it may increase the risk to donors after donation. Sickle cell trait is associated with microhematuria (up to $30 \%$ ), microalbuminuria (8\%), impairment of urinary concentration, and, less commonly, papillary necrosis and gross hematuria. ${ }^{30,31}$ Severe dehydration or hypoxia can expose patients with SCT to acute sickling episodes. Renal medullary carcinoma is a rare tumor reported in patients with SCT. The actual incidence of the carcinoma among patients with SCT is unknown; however, it comprises $<0.5 \%$ of all renal carcinomas. ${ }^{32}$ The association between SCT and CKD deserves careful review. ${ }^{33}$ A study conducted in the Democratic Republic of Congo reported that SCT accounted for $19 \%$ of the study population; however, it was not an independent determinant of CKD. In contrast, the traditional risk factors were the main determinants of CKD. ${ }^{34}$ However, a study by Derebail et al showed that SCT was twice as common in African Americans with ESKD than in those without ESKD (15\% vs. $7 \%$, respectively; $p<0.001) .{ }^{35}$ In a more recent study by Olaniran et al, patients with SCT demonstrated rapid decline in the estimated glomerular filtration rate (eGFR) by $0.45 \mathrm{ml} / \mathrm{min} / 1.73 \mathrm{~m}^{2} /$ year compared with adult Black patients with normal hemoglobin phenotype $(p<0.01) .{ }^{36,37}$

Policies regarding potential living donors with SCT are lacking. ${ }^{33}$ A survey conducted by Reese et al in the United States in 2008 reported that $83 \%$ of the transplantation centers did not have any policy for screening donors with SCT; 37\% indicated that they excluded donors with SCT; and $19 \%$ reported that they would consider donors with SCT. ${ }^{38}$ The likelihood of the acceptance of such donors was higher among centers with a high volume of living donor transplantations ( $>100 /$ year) $(p=0.03) .{ }^{38}$ Interestingly, our survey also showed a significant negative correlation between the prevalence of SCT in the countries of the respondents and their tendency to reject such potential donors.

One study reported on kidney transplantation from a donor with SCD. ${ }^{39}$ However, such donations may be associated with a higher risk than kidney donations from donors with SCT.

In our survey, the transplantation community was divided about the acceptance and suitability of donors with SCT. It is possible that centers with a higher volume of donors with SCT would be less likely to decline such individuals. Due to the high prevalence of SCT, further investigation of the relationship between this common condition and the development of CKD is warranted. The acceptance of donors with SCT would be impacted if the condition was associated with an increased risk of CKD.

\section{Active Heavy Smoking or Intermittent Illegal Drug Use} "Heavy smoking" (smoking more than 25 cigarettes/day) ${ }^{40,41}$ is likely to have poorer cumulative effects and more challenges in quitting than "light smoking." 40,41 In 2017, only 7\% of the transplantation programs in the United States excluded donors if they were current smokers. ${ }^{39}$ However, our respondents said that they would reject potential donors who are heavy smokers ( 2 packs per day "2PPD") at a much higher rate (38\%).

In addition to the negative effects of smoking on the general health of donors, several studies have reported negative effects of the smoking habit of kidney donors on the graft function and the survival of the recipient. ${ }^{42-44}$

Regarding the use of illicit drugs among potential donors: many centers have policies against the acceptance of such donors. This includes periodic use of drugs such as marijuana in any form (in countries where the drug is illegal). ${ }^{45}$ These policies are more likely due to psychosocial concerns about the donors, since studies have shown comparable medical outcomes between donors in both groups (drug users vs. nonusers). In a study by Ruckle et al, there was no difference in renal function between donors who used marijuana and those who did not at 12 months. ${ }^{46}$ In another study by Lin et al, using UNOS data on deceased donor kidney transplantation, donor history of cigarette smoking, but not intravenous drug use, was a risk factor for both graft and recipient survival. ${ }^{47}$ Data on the effects of drug use among living donors is limited because such individuals are typically excluded from donation. It is important to point out that public and health care professionals view each drug differently. As an example, there are fewer restrictions on the use of cannabis in potential KDs than on the use of cocaine. ${ }^{48}$

In a study conducted in $2017,52 \%$ of the transplantation programs accepted kidney donations from candidates after a specified abstinence period, as determined by a mental health professional on an individual basis. ${ }^{39}$ In our survey, there was no difference between the attitude of nephrologists and TS toward donors who intermittently used illegal drugs, although nephrologists appeared more confident in accepting actively smoking donors after advising them to quit the habit. 


\section{Urological Issues}

Urological issues, such as incidental renal cysts, asymptomatic kidney stones, remote history of renal colic, or discrepancy in the split function on nuclear renogram, are frequently encountered among living KDs.

Studies have assured that the presence of a simple renal cyst had no serious long-term ( 2 years) hazards ${ }^{49}$ and that a simple renal cyst or stage I renal cyst should not preclude kidney donation. ${ }^{50}$ In our survey, an incidentally identified solitary simple renal cyst was not considered a contraindication for kidney donation by the respondents.

Stones are not uncommon among KDs. Kidney stones may be identified incidentally in $10 \%$ of potential donors during imaging. Similarly, a study reported that $3 \%$ of the donors had a history of renal colic. ${ }^{51}$

Several guidelines permit donations from individuals with kidney stones. ${ }^{52}$ In general, kidney donations are accepted from asymptomatic potential donors with one small stone and negative results of metabolic investigations. ${ }^{52}$ However, only 33 to $48 \%$ of the centers accept kidneys from donors who have stones present bilaterally. ${ }^{20}$

There are several important factors to consider when evaluating donors with asymptomatic kidney stones, including the size of the stone $(2-3 \mathrm{~mm}),{ }^{53-55}$ the duration from last renal colic, ${ }^{20,45,53,54,56}$ and the results of metabolic evaluations. ${ }^{57}$ Donors are typically left with the stone-free kidney.

Online calculators may be useful for calculating the risk of recurrence of stones in the general population. ${ }^{58}$ However, the risk of recurrence in donors with small asymptomatic stones $(2-3 \mathrm{~mm})$ may be even lower $(0-2 \%)$ at 2 and 7 years' follow-up. ${ }^{53,54}$ Younger patients are at higher risk of recurrence of stones due to their longer life expectancy. ${ }^{55}$
In our survey, incidentally identified kidney stones or a history of renal colic was not considered contraindications for kidney donation by the majority of the respondents.

Renography is routinely performed as a part of donor assessment at some transplantation centers. Discrepancy of function between the two kidneys is common and usually minor (within $10-15 \%$ ) in up to $40 \%$ of the donors. ${ }^{59,60}$ However, CT renal volumetry provides a comparable specificity of $88 \%$ for discriminating split renal function at a threshold that could influence the choice of the kidney to be removed. ${ }^{61-63}$ In addition, CT renal volumetry is a more readily available test and provides additional information on renal and vascular anatomy. For these reasons, many transplant centers have replaced routine nuclear renogram with CT renal volumetry as part of living donor evaluation. ${ }^{62}$

Our question in this survey aimed to understand the approach of the transplantation community in cases of significant discrepancy in kidney function (e.g., $70 \%$ in the right kidney vs. $30 \%$ in the left kidney), as determined by nuclear renography. We observed a significant difference in the interpretation of split renal function by nuclear renogram between nephrologists and TS, even when the test was clearly abnormal. Literature suggests the use of CT renal volumetry as a more favorable screening modality.

- Table 6 summarizes the survey findings.

There are several strengths and limitations in our study. The survey was answered by 239 respondents, including 100 nephrologists and 139 TS, from 29 countries through three major international transplant societies (AST, ASTS, and ERA-EDTA). The number of participants in our survey was much larger than that of previous surveys distributed through UNOS in 2007 and 2017 (for instance, the survey

\section{Table 6 Summary of the survey findings}

Young potential KDs with persistent IMH (even at mild degree) are required to undergo further evaluation with kidney biopsy before donation, according to responders to this survey. However, up to one-third of the nephrologist and TS will ask for an alternative donor to avoid the hassle of kidney biopsy, which can be borderline or inconclusive.

The transplant community is divided about the acceptance and utility of donors with SCT. It is possible that centers with a higher prevalence of donors with SCT to be less likely to decline these donors.

Due to the high prevalence of SCT, further investigation of the relationship between this common condition and the development of CKD is warranted. If SCT does confer a risk of developing CKD, this will definitely impact the suitability and the acceptable of donors with SCT.

Active heavy smoking and intermittent illegal drug use alone are not viewed as contraindications for kidney donation by most physicians.

Nephrologists and TS did not differ in attitude regarding donors with IIDU. Nephrologist seems more confident to accept donors who are actively smoking with advice to quit afterward while TS would accept them more if no alternative donor available or would decline them completely.

Incidentally found kidney stone, old history of renal colic, and solitary simple renal cyst are not viewed per se as contraindications for kidney donation by the study population.

There is a significant difference in the interpretation of split renal function by nuclear renogram between nephrologists and transplant nephrologist even when the test is clearly abnormal. CT renal volumetry provides better screening modality.

Abbreviations: CKD, chronic kidney disease; CT, computed tomography; IIDU, intermittent illegal drug use; IMH, isolated microscopic hematuria; $\mathrm{KD}$, kidney donor; SCT, sickle cell trait; TS, transplant surgeon. 
distributed through UNOS in 2017 had 72 responses, with 44 medical directors and 28 surgical directors). This was due to the multinational nature of our study and the fact that we did not restrict participation to the directors of the transplant units.

Our survey also covered several challenging areas that had not been addressed by previous guidelines or surveys.

Potential living donors and recipients are typically assessed by separate health care teams to avoid any conflict of interest. ${ }^{64}$ Our survey was unique in exploring the difference between nephrologists and TS. The main objective of our survey was exploring the opinions of nephrologists and TS as a unified group, since the decisions of accepting MCLKDs are typically addressed through a multidisciplinary approach.

One of the limitations of our study is that respondents practicing in the United States were overrepresented (65\% of the total respondents were from the United States, whereas only $25 \%$ of worldwide renal transplantations occurred in the United States in 2019). ${ }^{65,66}$ This is because we did not have official access to directly approach the renal transplant units globally, and the respondents were reached through the international societies, many of which did not have any means to distribute the external studies.

Other potential limitations of the survey are the unknown response rates of the members of ERA-EDTA. This was due to the distribution of our survey through the transplant societies by web posting. The survey also did not account for multiple replies from the same unit. These do not critically affect the validity of our study, since the responses from ERA-EDTA constituted only $19 \%$ of the total responses and the fact that our survey was designed to explore the general opinions of the transplant providers in the international community and not the formal policies of the transplant units. Other assuring factors include the high completion rate of $99 \%$ and the comparisons made between our results and previous surveys, as outlined throughout the discussion.

\section{Conclusion}

In conclusion, this survey explored the opinions of many members of the international transplantation society regarding MCLKD with IMH, SCT, heavy smoking or IIDU, or urological issues.

Funding

None

Conflict of Interest

None declared.

\section{Acknowledgments}

We would like to thank the AST and the ASTS for distributing this external survey. We would also like to thank the ERA-EDTA for endorsing and distributing this survey for the promotion of education in general, without responsibility about the content of the survey. We would like to thank Dr. Osun Kwon for her editorial review and Dr. A. Awad for performing the statistical analysis.

\section{References}

1 Maggiore U, Cravedi P. The marginal kidney donor. Curr Opin Organ Transplant 2014;19(04):372-380

2 Reese PP, Feldman HI, McBride MA, Anderson K, Asch DA, Bloom RD. Substantial variation in the acceptance of medically complex live kidney donors across US renal transplant centers. Am J Transplant 2008;8(10):2062-2070

3 Maggiore U, Budde K, Heemann U, et al; ERA-EDTA DESCARTES working group. Long-term risks of kidney living donation: review and position paper by the ERA-EDTA DESCARTES working group. Nephrol Dial Transplant 2017;32(02):216-223

4 Muzaale AD, Massie AB, Wang M-C, et al. Risk of end-stage renal disease following live kidney donation. JAMA 2014;311(06): 579-586

5 Halverson CME, Wang JY, Poulson M, Karlin J, Crowley-Matoka M, Ross LF. Living kidney donors who develop kidney failure: excerpts of their thoughts. Am J Nephrol 2016;43(06):389-396

6 Kiberd BA, Tennankore KK. Lifetime risks of kidney donation: a medical decision analysis. BMJ Open 2017;7(08):e016490

7 Abramowicz D, Cochat P, Claas FHJ, et al. European Renal Best Practice Guideline on kidney donor and recipient evaluation and perioperative care. Nephrol Dial Transplant 2013;28(Suppl 2): ii1-ii71

8 Lentine KL, Kasiske BL, Levey AS, et al. KDIGO Clinical Practice Guideline on the Evaluation and Care of Living Kidney Donors. Transplantation 2017;101(8S):(Suppl 1):S1-S109

9 Abramowicz D, Cochat P, Claas FHJ, et al. European Renal Best Practice Guideline on kidney donor and recipient evaluation and perioperative care. Nephrol Dial Transplant 2015;30(11): 1790-1797

10 ESRD Risk Tool for Kidney Donor Candidates Accessed September 21, 2021 at: http://wwwtransplantmodelscom/esrdrisk/

11 Grams ME, Sang Y, Levey AS, et al; Chronic Kidney Disease Prognosis Consortium. Kidney-failure risk projection for the living kidney-donor candidate. N Engl J Med 2016;374(05): 411-421

12 Cantarelli C, Cravedi P. Criteria for living donation from marginal donors: one, no one, and one hundred thousand. Nephron 2019; 142(03):227-232

13 Lafranca JA, Spoon EQW, van de Wetering J, IJzermans JNM, Dor FJMF. Attitudes among transplant professionals regarding shifting paradigms in eligibility criteria for live kidney donation. PLoS One 2017;12(07):e0181846

14 Prevention CfDCa. Incidence of Sickle Cell Trait in the US. Accessed April 13, 2020 at: https://wwwcdcgov/ncbddd/sicklecell/features/keyfinding-traithtml

15 Jastaniah W. Epidemiology of sickle cell disease in Saudi Arabia. Ann Saudi Med 2011;31(03):289-293

16 Adam MA, Adam NK, Mohamed BA. Prevalence of sickle cell disease and sickle cell trait among children admitted to Al Fashir Teaching Hospital North Darfur State, Sudan. BMC Res Notes 2019;12(01):659

17 Shabbir S, Nadeem M, Sattar A, et al. Type and frequency of hemoglobinopathies, diagnosed in the area of Karachi, in Pakistan. Cogent Med 2016;3(01):1188875

18 Piel FB, Patil AP, Howes RE, et al. Global distribution of the sickle cell gene and geographical confirmation of the malaria hypothesis. Nat Commun 2010;1(01):104

19 Hashmi NK, Moiz B, Nusrat M, Hashmi MR. Chromatographic analysis of $\mathrm{Hb} \mathrm{S}$ for the diagnosis of various sickle cell disorders in Pakistan. Ann Hematol 2008;87(08):639-645

20 Garg AX, Levey AS, Kasiske BL, Cheung M, Lentine KLKDIGO Clinical Practice Guideline on the Evaluation and Care of Living Kidney Donors Work Group and Evidence Review Team. Application of the 2017 KDIGO Guideline for the Evaluation and Care of Living Kidney Donors to Clinical Practice. Clin J Am Soc Nephrol 2020;15(06):896-905 
21 Kido R, Shibagaki Y, Iwadoh K, et al. Persistent glomerular hematuria in living kidney donors confers a risk of progressive kidney disease in donors after heminephrectomy. Am J Transplant 2010;10(07):1597-1604

22 Hassan EA, Ali TZ, Abdulbaki A, Ibrahim IA, Almanae HM, Aleid HA. Histopathologic findings of potential kidney donors with asymptomatic microscopic hematuria: impact on donation. Transplant Proc 2017;49(08):1729-1732

23 Choi SR, Sun IO, Hong YA, et al. The role of kidney biopsy to determine donation from prospective kidney donors with asymptomatic urinary abnormalities. Transplant Proc 2012;44(01): $11-13$

24 Kumar V, Saha M, Hanaway M, Locke J, Julian B, Gaston R. Very low levels of microscopic hematuria in potential living kidney donors is associated with pathology that precludes donation. Transplantation 2018;102:S138

25 Vadivel N, Stankovic A, Rennke HG, Singh AK. Accepting prospective kidney donors with asymptomatic urinary abnormalities: are we shooting in the dark? Kidney Int 2007;71(02):173-177

26 Imafuku A, Nozu K, Sawa N, Nakanishi K, Ubara Y. How to resolve confusion in the clinical setting for the diagnosis of heterozygous COL4A3 or COL4A4 gene variants? Discussion and suggestions from nephrologists. Clin Exp Nephrol 2020;24(08):651-656

27 Choi C, Ahn S, Min SK, et al. Midterm outcome of kidney transplantation from donors with thin basement membrane nephropathy. Transplantation 2018;102(04):e180-e184

28 Carasi C, Van't Hoff WG, Rees L, Risdon RA, Trompeter RS, Dillon MJ. Childhood thin GBM disease: review of 22 children with family studies and long-term follow-up. Pediatr Nephrol 2005; 20(08):1098-1105

29 Hartono C. Live Kidney Donors with Microscopic Hematuria. The Living Donor Community of Practice of AST. Accessed September 21, 2021 at: https://www.myast.org/sites/default/files/pdf/Chapter\%208\%20\%20Microscopic\%20hematuria\%20in\%20kidney \%20donors.pdf

30 Tsaras G, Owusu-Ansah A, Boateng FO, Amoateng-Adjepong Y. Complications associated with sickle cell trait: a brief narrative review. Am J Med 2009;122(06):507-512

31 Sesso R, Almeida MA, Figueiredo MS, Bordin JO. Renal dysfunction in patients with sickle cell anemia or sickle cell trait. Braz J Med Biol Res 1998;31(10):1257-1262

32 Beckermann KE, Sharma D, Chaturvedi S, et al. Renal medullary carcinoma: establishing standards in practice. J Oncol Pract 2017; 13(07):414-421

33 Shaw C, Sharpe CC. Could sickle cell trait be a predisposing risk factor for CKD? Nephrol Dial Transplant 2010;25(08):2403-2405

34 Mukendi K, Lepira FB, Makulo JR, Sumaili KE, Kayembe PK, Nseka MN. Sickle cell trait is not associated with chronic kidney disease in adult Congolese patients: a clinic-based, cross-sectional study. Cardiovasc J Afr 2015;26(03):125-129

35 Derebail VK, Nachman PH, Key NS, Ansede H, Falk RJ, Kshirsagar AV. High prevalence of sickle cell trait in African Americans with ESRD. J Am Soc Nephrol 2010;21(03):413-417

36 Olaniran KO, Allegretti AS, Zhao SH, et al. Kidney function decline among black patients with sickle cell trait and sickle cell disease: an observational cohort study. J Am Soc Nephrol 2020;31(02): 393-404

37 Nath KA, Vercellotti GM. Renal functional decline in sickle cell disease and trait. J Am Soc Nephrol 2020;31(02):236-238

38 Reese PP, Hoo AC, Magee CC. Screening for sickle trait among potential live kidney donors: policies and practices in US transplant centers. Transpl Int 2008;21(04):328-331

39 Kitchlu A, Adhikari N, Burns KEA, et al. Outcomes of sustained low efficiency dialysis versus continuous renal replacement therapy in critically ill adults with acute kidney injury: a cohort study. BMC Nephrol 2015;16:127-127

40 Wilson D, Wakefield M, Owen N, Roberts L. Characteristics of heavy smokers. Prev Med 1992;21(03):311-319
41 Killen JD, Fortmann SP, Telch MJ, Newman B. Are heavy smokers different from light smokers? A comparison after 48 hours without cigarettes. JAMA 1988;260(11):1581-1585

42 Aref A, Sharma A, Halawa A. Smoking in Renal Transplantation; Facts Beyond Myth. World J Transplant 2017;7(02):129-133

43 Heldt J, Torrey R, Han D, et al. Donor smoking negatively affects donor and recipient renal function following living donor nephrectomy. Adv Urol 2011;2011:929263-929263

44 Underwood PW, Sheetz KH, Cron DC, Terjimanian MN, Englesbe MJ, Waits SA. Cigarette smoking in living kidney donors: donor and recipient outcomes. Clin Transplant 2014;28(04): 419-422

45 Donor Selection Criteria. UC Davis Health/ Transplant Center/ Living Donation. Accessed April 27, 2020 at: https://health. ucdavis.edu/transplant/livingdonation/donor_criteria.html

46 Ruckle D, Keheila M, West B, et al. Should donors who have used marijuana be considered candidates for living kidney donation? Clin Kidney J 2018;12(03):437-442

47 Lin SJ, Koford JK, Baird BC, et al. Effect of donors' intravenous drug use, cigarette smoking, and alcohol dependence on kidney transplant outcome. Transplantation 2005;80(04):482-486

48 Piccoli GB, Soragna G, Putaggio S, et al. Drug use and kidney donation: what are high-risk behaviors today? Transplant Proc 2006;38(05):1221-1223

49 Grotemeyer D, Voiculescu A, Iskandar F, et al. Renal cysts in living donor kidney transplantation: long-term follow-up in 25 patients. Transplant Proc 2009;41(10):4047-4051

50 Simms RJ, Ong AC. How simple are 'simple renal cysts'? Nephrol Dial Transplant 2014;29(Suppl 4):iv106-iv112

51 Lorenz EC, Lieske JC, Vrtiska TJ, et al. Clinical characteristics of potential kidney donors with asymptomatic kidney stones. Nephrol Dial Transplant 2011;26(08):2695-2700

52 Tatapudi VS, Goldfarb DS. Differences in national and international guidelines regarding use of kidney stone formers as living kidney donors. Curr Opin Nephrol Hypertens 2019;28(02): 140-147

53 Serur D, Charlton M, Juluru K, et al. Long term follow up of kidney donors with asymptomatic renal stones. Nephrology (Carlton) 2017;22(08):649-651

54 Serur D. Should kidney donors with asymptomatic small stones be allowed to donate? Living Donor Community of Practice of AST. Accessed September 21, 2021 at: https://www.myast.org/sites/default/files/pdf/Chapter\%206\%20\%20\%20Donors\% 20with\%20stones.pdf

55 Delmonico FCouncil of the Transplantation Society. A Report of the Amsterdam Forum On the Care of the Live Kidney Donor: Data and Medical Guidelines. Transplantation 2005;79(6, Suppl)S53-S66

56 Kasiske BL, Ravenscraft M, Ramos EL, Gaston RS, Bia MJ, Danovitch GMAd Hoc Clinical Practice Guidelines Subcommittee of the Patient Care and Education Committee of the American Society of Transplant Physicians. The evaluation of living renal transplant donors: clinical practice guidelines. J Am Soc Nephrol 1996;7(11): 2288-2313

57 (OPTN) OPaTN. Organ Procurement and Transplantation Network (OPTN) Policies. Accessed April 12, 2020 at: https://optntransplanthrsagov/media/1200/optn_policiespdf\#nameddest=Policy_14

$58 \mathrm{MD} \mathrm{CbQ}$. Predict risk of recurrent kidney stones. Accessed September 21, 2021 at: https://qxmd.com/calculate/calculator_3/roks-recurrence-of-kidney-stone-2014

59 Shokeir AA, Gad HM, el-Diasty T. Role of radioisotope renal scans in the choice of nephrectomy side in live kidney donors. J Urol 2003;170(2 Pt 1):373-376

60 Oh CK, Yoon SN, Lee BM, et al. Routine screening for the functional asymmetry of potential kidney donors. Transplant Proc 2006;38 (07):1971-1973

61 Habbous S, Woo J, Lam NN, et al. The efficiency of evaluating candidates for living kidney donation: a scoping review. Transplant Direct 2018;4(10):e394-e394 
62 Habbous S, Garcia-Ochoa C, Brahm G, Nguan C, Garg AX. Can split renal volume assessment by computed tomography replace nuclear split renal function in living kidney donor evaluations? A systematic review and meta-analysis. Can J Kidney Health Dis 2019;6:2054358119875459

63 Tanriover B, Fernandez S, Campenot ES, et al. Live donor renal anatomic asymmetry and posttransplant renal function. Transplantation 2015;99(08):e66-e74

64 Wright L, Faith K, Richardson R, Grant DJoint Centre for Bioethics, University of Toronto, Toronto, Ont. Ethical guidelines for the evaluation of living organ donors. Can J Surg 2004;47(06): 408-413
65 Searing L. The Big Number: 39,717 organ transplants in the U.S. last year. Accessed March 2, 2020 at: https://wwwwashingtonpostcom/health/the-big-number-39717-organ-transplantsin-the-us-last-year/2020/02/28/2f9c376e-5976-11ea-9000f3cffee23036_storyhtml

66 Organisation TSNT. World Transplant Registry reports 139,024 transplants performed worldwide last year, up $2.3 \%$. Accessed June 24, 2020 at: https://wwwlamoncloagobes/lang/en/gobierno/news/Paginas/2019/20180828transplantaspx\#: :text=In\% 20total\%2C\%203\%2C313\%20kidney\%20transplants,six\%20intestinal\%20transplants\%20were\%20performed 